\title{
Pilosella hoppeana subsp. sicula Di Grist., Gottschl. \& Raimondo (Asteraceae), a new endemic subspecies from Sicily (Italy)
}

\author{
Emilio Di Gristina, Günter Gottschlich \& Francesco Maria Raimondo
}

\begin{abstract}
DI GRISTINA, E., G. GOTTSCHLICH \& F.M. RAIMONDO (2016). Pilosella hoppeana subsp. sicula Di Grist., Gottschl. \& Raimondo (Asteraceae), a new endemic subspecies from Sicily (Italy). Candollea 71: 7-12. In English, English abstract. DOI: http://dx.doi.org/10.15553/c2016v711a2 Pilosella hoppeana subsp. sicula Di Grist., Gottschl. \& Raimondo (Asteraceae), a new endemic subspecies from the Madonie and Nebrodi Mountains (Sicily, Italy), is described and illustrated. It is morphologically close to Pilosella hoppeana subsp. macrantha (Ten.) S. Bräut. \& Greuter, but the two subspecies can be distinguished by the indument on the bracts. Its morphology, distribution, ecology, taxonomic relationships are commented and a key to the Pilosella hoppeana (Schult.) F.W. Schultz \& Sch. Bip. aggregate is provided.
\end{abstract}

\section{Keywords}

ASTERACEAE - Pilosella - Sicily - Madonie - Nebrodi Mountains - Taxonomy

\footnotetext{
Addresses of the authors:

EDG : Dipartimento STEBICEF, Sezione di Botanica ed Ecologia Vegetale, Università degli Studi di Palermo, via Archirafi 38, 90123 Palermo, Italy. E-mail: emilio.digristina@unipa.it

GG: Hermann-Kurz-Straße 35, 72074 Tübingen, Germany.

FMR: Dipartimento STEBICEF, Sezione di Botanica ed Ecologia Vegetale, Università degli Studi di Palermo, via Archirafi 38, 90123 Palermo, Italy. 


\section{Introduction}

According to ZAHN (1923), Pilosella Vaill. [under Hieracium L.] comprises 181 "basic" species or species aggregates distributed from Eurasia to north-western Africa (see also SELL \& WEST, 1975). The Pilosella hoppeana (Schult.) F.W. Schultz \& Sch. Bip. aggr. corresponding to Hieracium sect. Pilosellina Zahn, is very polymorphic. $Z_{\mathrm{AHN}}$ (1923) recognised 25 subspecies, distributed from central and southern Europe to the Caucasus. These taxa are hemicryptophyte rosulate, flowering between May and early August, and they differ in size, shape, color and indumentum of bracts (Gotтschlich, 2009). According to Greuter (2008) this group consist only of three subspecies: P. hoppeana subsp. hoppeana, subsp. macrantha (Ten.) S. Bräut. $\&$ Greuter and subsp. cilicica (Nägeli \& Peter) P.D. Sell \& C. West. Pilosella hoppeana subsp. hoppeana, described by Schultes (1814) from the Alps as Hieracium hoppeanum Schult., is a very variable species. It occurs mainly in the Alps, but also some records from Abruzzo are given. Pilosella hoppeana subsp. macrantha was described in Hieracium as $H$. pilosella var. macranthum Ten. by Tenore (1830) and later recognized at the species level by TENORE $(1835-1838)$ as H. macranthum (Ten.) Ten. The type material was collected on Mt. Velino and Mt. Majella (Abruzzo, in central Italy). It is an Italian endemic taxon probably restricted to the centralsouthern Apennines and Sicily (Di Gristina et al., 2013).

Unlike the narrow treatment in Euro+Med (2015), we consider Pilosella hoppeana subsp. macrantha as a separate taxon from $P$. hoppeana subsp. hoppeana, because the two subspecies show clear differences in phytogeographical, morphological and ecological features. Also, as pointed out by GotTschlich $(2009,2011)$, the epithet macranthum was often misapplied for other taxa of the $P$. hoppeana aggregate, especially those occurring in south-eastern Europe that must be named P. leucopsilon (Arv.-Touv.) Gottschl. (= Hieracium leucopsilon Arv.Touv., Pilosella hoppeana subsp. testimonialis (Peter) P.D. Sell \& C.West, P. hoppeana subsp. troica (Zahn) P.D. Sell \& C. West, P. pilisquama (Nägeli \& Peter) Dostál).

In Italy the group is represented by $P$. hoppeana subsp. hoppeana and P. hoppeana subsp. macrantha (Pignatti, 1982; Greuter, 2008). According to Pignatti (1982) and Greuter (2008), only P. hoppeana subsp. macrantha occurs in Sicily where the taxon is limited to the Madonie (North-Central Sicily) (Gussone, 1844; Strobl, 1878; Lojacono Pojero, 1903) and Nebrodi Mountains (NorthEast Sicily) (Gussone, 1844; Lojacono Pojero, 1903). The plants of the Madonie grow on calcareous and quartzarenitic stony pastures and slopes of the main mountains (Monte dei Cervi, Monte Quacella, Monte Scalone, Monte Cavallo, Monte San Salvatore, etc...), between 1400 and 1850 m, whereas in the Nebrodi mountains, the taxon occurs only on the quartzarenitic slopes of Monte Campanito, between 1390 and $1430 \mathrm{~m}$. The Sicilian populations are very variable, especially with respect to the proportion of simple and glandular hairs on the involucral bracts. Indeed, individuals with dense simple hairs and sparse or absent glandular hairs on the bracts are often found, in the same place and apparently without intermediate forms, growing together with others that have dense glandular hairs and sparse or absent simple hairs. Lojacono Pojero (1903) referred the individuals with dense simple hairs to Hieracium macranthum (三Pilosella hoppeana subsp. macrantha) and those with dense glandular hairs to Hieracium hoppeanum (三Pilosella boppeana subsp. hoppeana). More recent floras (Pignatti, 1982; Greuter, 2008) following ZaHN (1923) however consider that a single taxon is present in Sicily, corresponding to P. hoppeana subsp. macrantha.

In order to underline the level of morphological and genetic variability within and among Italian populations of the $P$. hoppeana aggr., an integrated morphological, karyological and isoenzyme approach was used (Di Gristina et al., 2013). Ten populations from the Alps, Abruzzo, Calabria and Sicily were studied. The combined analyses confirmed the presence in Italy of P. hoppeana subsp. hoppeana (Alps) and P. hoppeana subsp. macrantha (Peninsula and Sicily). Calabrian populations were included in P. leucopsilon. The Sicilian populations with mainly simple hairs on the bracts were referred to $P$. hoppeana subsp. macrantha s.str., whereas those characterised by mainly glandular hairs on the bracts showed genetic dissimilarities with the mainly simple-haired Sicilian populations and the other Italian P. hoppeana aggr. taxa investigated (Di Gristina et al., 2013).

Based on the above studies, we describe the Sicilian populations characterised by mainly glandular hairs on the bracts as a new subspecies belonging to the $P$. hoppeana aggr.

Pilosella hoppeana subsp. sicula Di Grist., Gottschl. \& Raimondo, subspec. nova (Fig. 1, 2, 3A).

Typus: ITALy. Sicily: Monti Madonie, Monte Scalone, Polizzi Generosa (Palermo), 3750'28”N, 1401'06”E, 1510 m, 15.VI.2011, Di Gristina 101238 (holo-: PAL!; iso-: FI!, Hb. Gottschlich-60238!, PAL-Gr!).

A Pilosella hoppeana subsp. macrantha (Ten.) S. Bräut. E Greuter squamis pilis glanduliferis, 0.2-1.1(-1.4) mm longis, modice densis vel subdensis, et pilis simplicibus, $0.4-1.5 \mathrm{~mm}$ longis, sparsis vel nullis differt.

Plant perennial, rosulate. Rhizome slender, cylindrical, fibrous, horizontal or oblique. Stolons 1-3, epigeal, short or slightly elongated, 3-7 cm long; axis stout or slender (1.3$2.1 \mathrm{~mm}$ in diam.), with dense stellate hairs; internodes short, 0.4$1 \mathrm{~cm}$ long; stolons leaves green, obovate or lanceolate-obovate, $1.5-3.5 \times 0.5-1 \mathrm{~cm}$, with dense stellate hairs beneath, with moderately to rather dense, $3-5 \mathrm{~mm}$ long, simple hairs on both leaf surfaces. Stem erect or ascending, simple, (5-)8-20 

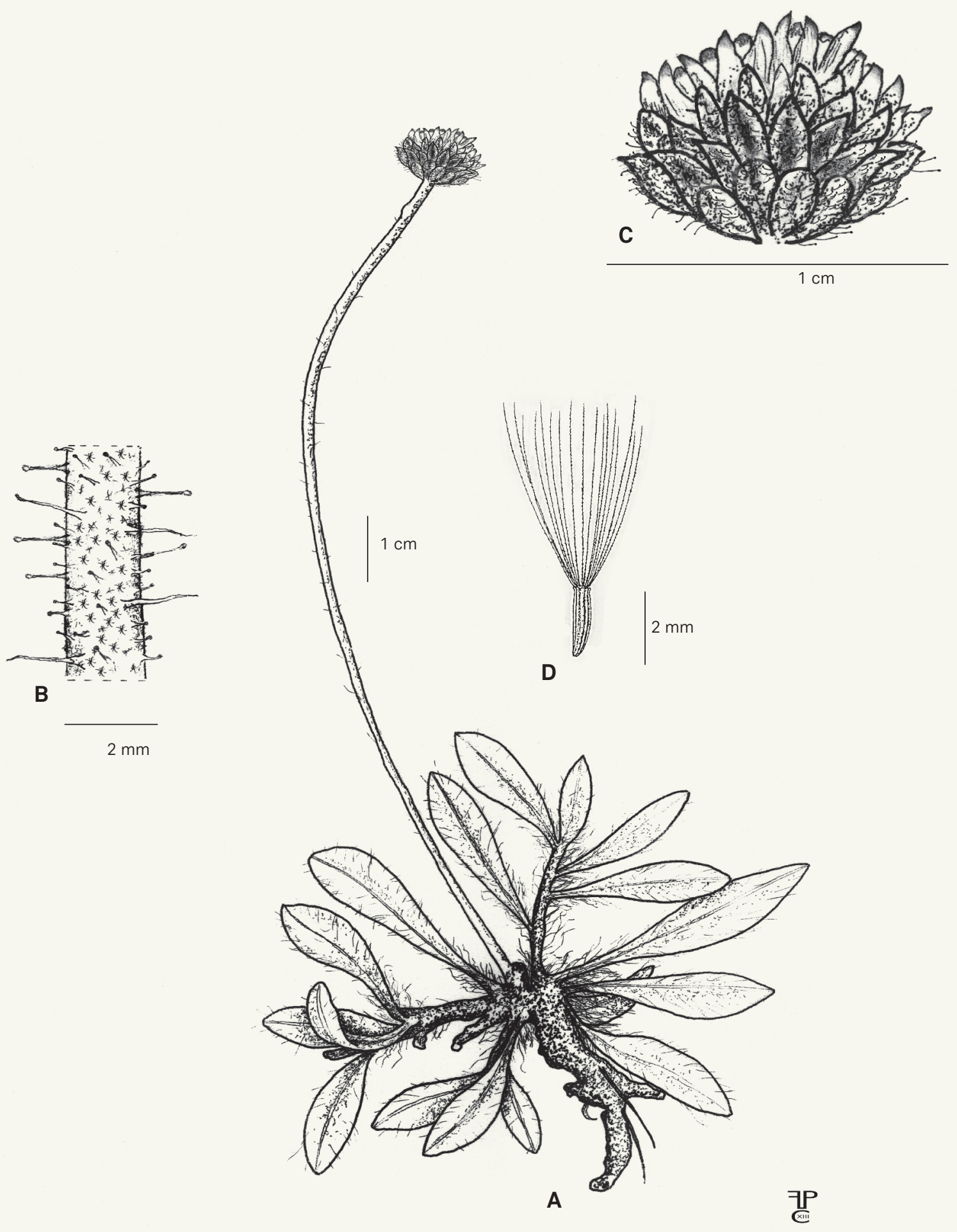

Fig. 1. - Pilosella hoppeana subsp. sicula Di Grist., Gottschl. \& Raimondo. A. Habit; B. Detail of apical stem; C. Capitulum; D. Achene. [Di Gristina 101238, PAL] [Drawing: F.P. Campione] 


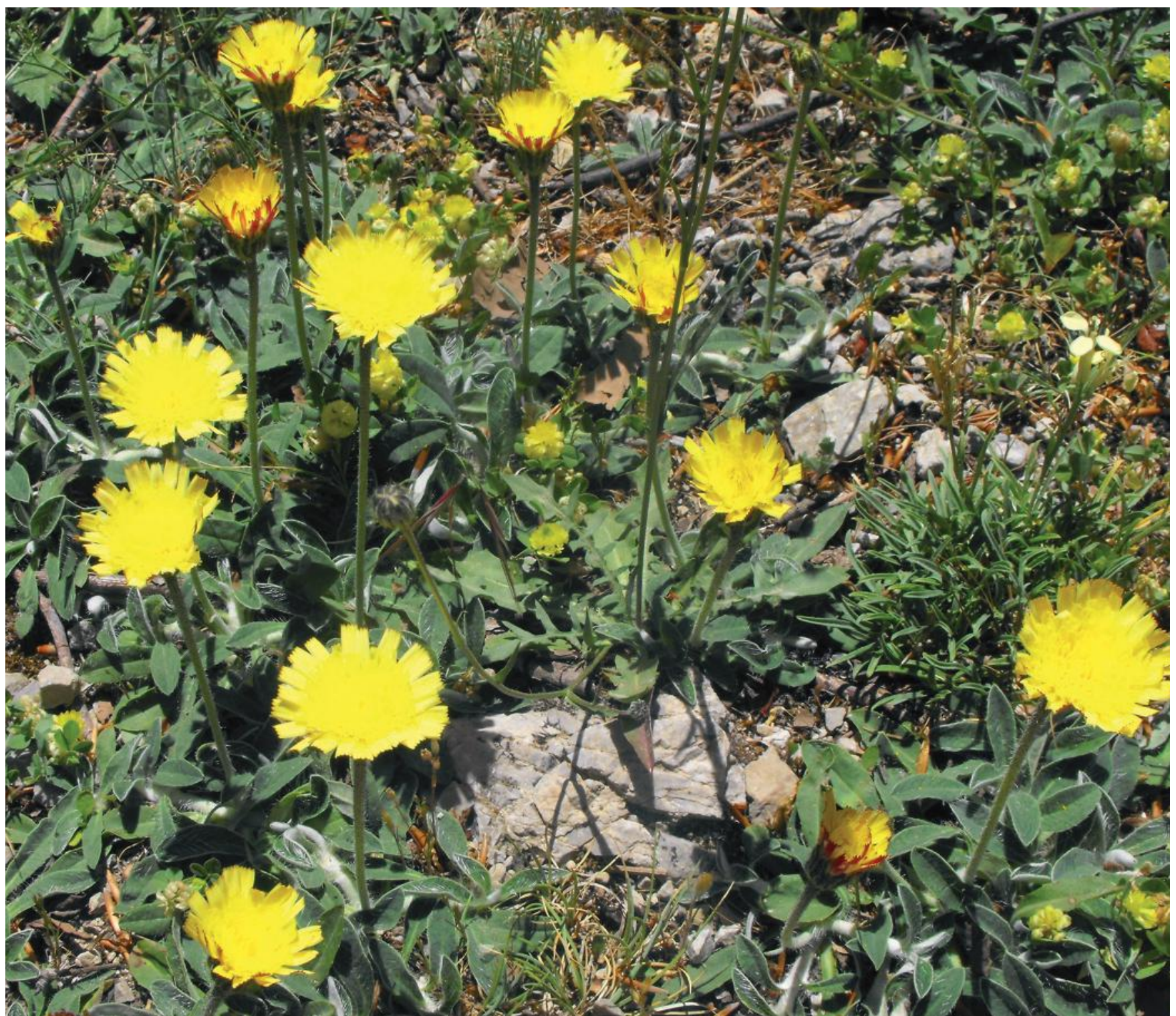

Fig. 2. - Blooming populations of Pilosella hoppeana subsp. sicula Di Grist., Gottschl. \& Raimondo in Mt. Scalone (Madonie mountains). [Photos: E. Di Gristina]

$(-25) \mathrm{cm}$ high, green, beneath with sparse to moderately dense, 1-4(-6) mm long, simple hairs, sparse, 0.2$0.3 \mathrm{~mm}$ long, glandular hairs and moderately dense stellate hairs, above with sparse or no, 0.4-1.5 mm long, simple hairs, moderately to rather dense, $0.2-1.1$ $(-1.4) \mathrm{mm}$ long, glandular hairs and dense stellate hairs. Rosette-leaves 3-5(-7), green, petiolate; lamina oblanceolatespathulate, $3.5-5.5 \times 0.7-1.3 \mathrm{~cm}$, entire, obtuse, rounded or acute, attenuate, above with moderately to rather dense, 3-5 mm long, simple hairs, beneath with dense stellate hairs and moderately to rather dense, 3-6 mm long, simple hairs, mostly along the midrib and the petiole. Cauline-leaves 0-1
(-2), like bracts. Capitula 1(-2). Involucre 9-13 mm long, subglobose. Involucral bracts in a few series, greenish-grey, clearer at the margin, 2-4 mm wide, the outer ovate, obtuse or rounded, the inner lanceolate, acute, with sparse or no, 0.4-1.5 mm long, simple hairs, blackish at the basis and whitish at the apex, with moderately to rather dense, 0.21.1(-1.4) mm long, glandular, blackish or yellowish glands, black peduncle, and stellate hairs. Ligules lingulate, yellow, the outer with a dark red stripe on outer face. Styles yellow. Achenes 1.9-2.5 mm long, blackish brown. Pappus 3-4 mm long, whitish. 

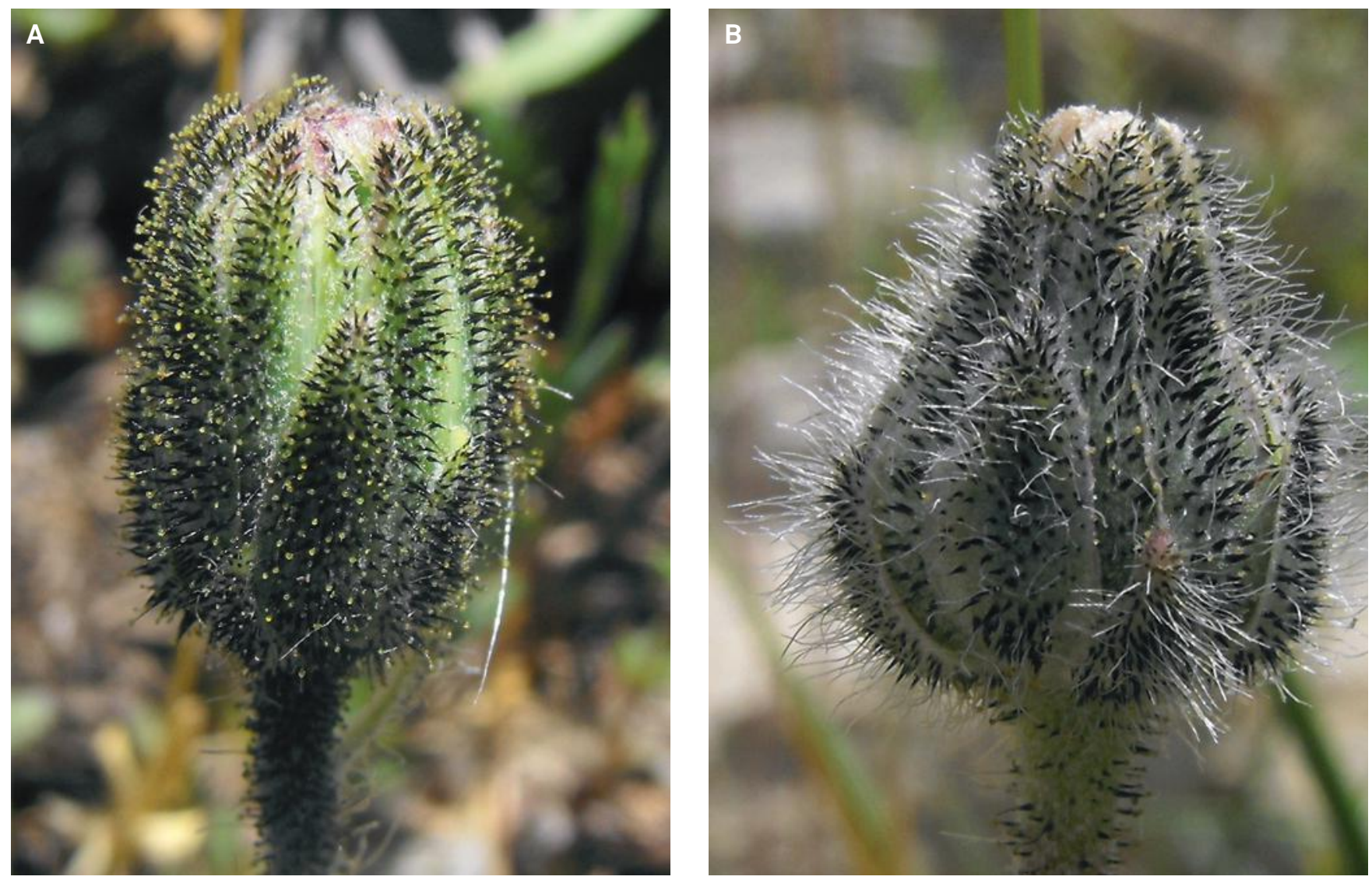

Fig. 3. - Details of the indumentum of the bracts. A. Pilosella hoppeana subsp. sicula Di Grist., Gottschl. \& Raimondo; B. P. hoppeana subsp. macrantha (Ten.) S. Bräut. \& Greuter. [Photos: E. Di Gristina]

Etymology. - The epithet "sicula" refers to the Sicily region, where the subspecies grows.

Phenology. - Flowering time: end of May-first decade of July (Fig. 2). Fruiting time: June-July.

Distribution and ecology. - Pilosella hoppeana subsp. sicula is endemic to the Madonie (North Sicily) and Nebrodi mountains (North East Sicily) (Fig. 3). In the Madonie mountains, the new subspecies occurs on the quartzarenitic stony pastures and rocky slopes of Monte Scalone, Monte dei Pini, Monte Cavallo, Monte San Salvatore, between 1400 and 1850 m. It is also occasionally growing on the limestone rocky slopes of Monte dei Cervi, Monte Quacella and Cozzo del Filatore. In the Nebrodi mountains, the new taxon is represented by a small population consisting approximately of 50 individuals occurring only on the quartzarenitic slopes of Monte Campanito (Nicosia, Enna), at the border of Fagus sylvatica L. forest, between 1390 and $1430 \mathrm{~m}$ a.s.1. Regarding to phytosociological aspects, Pilosella hoppeana subsp. sicula belongs to the associations of the "Plantaginion cupanii and Armerion nebrodensis alliances” (Brullo \& Grillo, 1978; Brullo, 1984).
Conservation status. - The new taxon is know from eight locations within the Protected Areas of Madonie and Nebrodi. Despite its restricted range, Pilosella hoppeana subsp. sicula is not facing any threat in the wild and a preliminary conservation status assessment of "Least Concern" [LC] following IUCN (2012) is appropriate.

Notes. - Pilosella hoppeana subsp. sicula belongs to the $P$. hoppeana aggr., which includes perennials plants, with few, very short and stout stolons; oblanceolate to oblong leaves, entire, acute to obtuse, with simple hairs on both surfaces and the margin and dense stellate hairs beneath and rarely also above; stems with a single capitulum, 0-1 cauline leaves, with numerous simple hairs and numerous to dense glandular and stellate hairs; light or dark green bracts, the outer ovate, the inner lanceolate, rounded to obtuse or subacute, with 0 to numerous simple hairs, 0 to numerous glandular hairs and dense stellate hairs; yellow ligules, with a dark red stripe on outer face; blackish brown achenes.

Within this complex, the new subspecies is close to P. hoppeana subsp. macrantha, but the two subspecies can be morphologically distinguished by the indumentum on the 
bracts, although sometimes occurring in sympatry. Pilosella hoppeana subsp. sicula shows moderately to rather dense, 0.21.1(-1.4) $\mathrm{mm}$ long, glandular hairs and few or no, $0.4-1.5 \mathrm{~mm}$ long, simple hairs on the bracts (Fig. 3A), while P. hoppeana subsp. macrantha presents bracts without or with few glandular hairs (0.1-0.5 mm long) and moderately to rather dense simple hairs (1-4 mm long) (Fig. 3B). The identification key below shows how the new subspecies can be distinguished from all the taxa of the Pilosella hoppeana aggr.

\section{Key to the Pilosella hoppeana aggregate}

1. Leaves with dense stellate hairs above ............ .................. P. hoppeana subsp. cilicica

1a. Leaves without stellate hairs above $\ldots \ldots \ldots \ldots \ldots 2$

2. Bracts $1.5-2 \mathrm{~mm}$ wide ............. P. leucopsilon

2a. Bracts 2-4 mm wide. . . . . . . . . . . . . . . . 3

3. Bracts blackish, pinkish-white at the margin........ ............... P. hoppeana subsp. hoppeana

3a. Bracts greenish-grey to greenish-white, whitish at the margin ..................

4. Bracts with moderately to rather dense, $0.2-1.1(-1.4) \mathrm{mm}$ long, glandular hairs and 0 to few, $0.4-1.5 \mathrm{~mm}$ long, simple hairs............... P. hoppeana subsp. sicula

4a. Bracts with 0 to few, 0.1-0.5 mm long, glandular hairs and moderately to rather dense simple, 1-4 mm long, simple hairs .............. P. hoppeana subsp. macrantha

\section{Acknowledgements}

The authors are grateful to Prof. Werner Greuter, "Herbarium Mediterraneum Panormitanum", for constructive suggestions and critical revision of the text. Thanks are due also to Dott. F. P. Campione, Dipartimento di Scienze Cognitive of University of Messina, for the drawing in Figure 1. Financial support by the International Foundation pro Herbario Mediterraneo and by Università degli Studi di Palermo (Fondi di Ateneo per la Ricerca) are acknowledged.

\section{References}

Brullo, S. (1984). Contributo alla conoscenza della vegetazione delle Madonie (Sicilia settentrionale). Boll. Accad. Gioenia Sci. Nat. Catania 16 : 351-420.

Brullo, S. \& M. Grillo (1978). Ricerche fitosociologiche sui pascoli dei Monti Nebrodi (Sicilia settentrionale). Notiz. Soc. Fitosociol. 13 : 26-61.

Di Gristina, E., G. Domina, G. Gottschlich, P. Mazzola \& A. Geraci (2013). Morphological and genetic diversity within Pilosella hoppeana aggr. (Asteraceae) in Italy and taxonomic implications. Pl. Biosyst. 147: 788-799.

Euro+Med (2015). Euro+Med PlantBase - The information resource for Euro-Mediterranean plant diversity [http://ww2.bgbm.org/ EuroPlusMed].

Gotтschlich, G. (2009). Die Gattung Hieracium L. (Compositae) in der Region Abruzzen (Italien). Eine floristisch-taxonomische Studie. Stapfia 89.

Gotтschlich, G. (2011). Hieracium. Pilosella [notes and new combinations]. In: Greuter, W. \& T. Raus (ed.), Med-Checklist Notulae, 30. Willdenowia $41: 314-317$.

Greuter, W. (2008). Med-checklist: a critical inventory of vascular plants of the circum-mediterranean countries. 2, Dicotyledones (Compositae). OPTIMA Secretariat, Palermo, Berlin.

Gussone, G. (1844). Fl. Sicul. Syn. 2. Neapoli.

IUCN (2012). IUCN Red List Categories and Criteria Version 3.1. $2^{\text {nd }}$ ed. IUCN Species Survival Commission, Gland \& Cambridge.

Lojacono Pojero, M. (1903). Fl. Sicul. 2(1). Palermo.

Pignatti, S. (1982). Fl. Ital. 3. Edagricole, Bologna.

Schultes, J.A. (1814). Oestr. Fl. 2.2 $2^{\text {nd }}$ ed. C. Schaumburg, Wien.

Sell, P.D. \& C. West (1975). Pilosella Hill. In: Davis, P.H. (ed.), Fl. Turkey 5 : 747-763. University Press, Edinburgh.

Strobl, P.G. (1878). Flora der Nebroden 2. Flora 61: 331-334.

Tenore, M. (1830). Fl. Napol. 4. Napoli.

Tenore, M. (1835-1838). Fl. Napol. 5. Napoli.

Z AHN, K.H. (1923). Compositae-Hieracium. In: Engler, H.G.A. (ed.), Pflanzenr. 82(IV.280): 1151. Engelmann. 